\title{
Buday-Sántha Andrea \\ A MÉDIA ÉS A NYILVÁNOSSÁG SZERKEZETVÁLTOZÁSÁNAK HATÁSA A PR ELVEIRE ÉS ETIKÁJÁRA
}

\section{Absztrakt}

A tanulmány a média, PR területén tapasztalható változások adta kutatási keretek közt, arra keresi a választ, hogy a világunkban zajló gyors változások milyen irányba mozgatják a média, a nyilvánosság szerkezetét, a PR kereteit, és mindezek milyen új elvek és etikai intézmények alkalmazását kívánják meg a PR gyakorlóitól.

A fogalmi tisztázások mellett a kutatás célja, hogy átfogó képet adjon a globális és lokális változásoknak a médiára, a nyilvánosságra, PR-re gyakorolt hatásairól, a bekövetkező szerkezetváltozásokról, valamint a PR elveiről és etikai irányvonalairól. A főbb hipotézisek: A média és a nyilvánosság szerkezetváltozása, paradigmaváltása következett be. A PR tevékenységnek követnie kell a külső környezet változásait. A PR újrafogalmazott elvek és etikus vállalati működés mentén működtethető hatékonyan.

Jelen tanulmány a témával kapcsolatos nemzetközi és a hazai szakirodalom áttekintése mellett a szerző korábbi empirikus kutatásaira alapozza megállapításait.

A globális trendek és a koronavírus járvány is új irányokra és új megoldásokra készteti a médiát, és a PR szakma művelőit. A PR tevékenységnek követnie kell a külső környezet változásaira figyelemmel újrafogalmazott elméleti és gyakorlati elveket, külön súllyal az etikus vállalati működésre, mely nélkül nincs eredményes PR tevékenység.

A lefolytatott kutatások eredményeire építő fogalmi tisztázások és megállapítások hozzájárulnak a kommunikációtudomány és a kapcsolódó elméleti területek fejlődéséhez, miközben hasznosítható ismereteket és eredményeket nyújt a kommunikációs kutatói, oktató és a témakör iránt érdeklődök számára.

Kulcsszavak: média; PR; etika

\section{Bevezető}

Az információs társadalmak felgyorsult világában zajló folyamatok az élet valamennyi területét érintő változásokat hoznak magukkal. A trendek a szervezeti kommunikációra, a public relations (PR) szakmára, a médiára is komoly hatást gyakorolnak, és az új kihívások új válaszokat és megoldásokat kívánnak. A Grayling hálózat 2011. évi szakmai kutatásának eredményei szerint a PR-szakma gyakorlói a változásokat érzékelik, de korszakváltással még nem szembesültek (Szeles, Szűcs \& Varga, 2013). Ma már azonban a paradigmaváltást számtalan tényező összessége eredményezi. Ezek közül a legfontosabbak bemutatásával kívánom ráirányítani a figyelmet a PR-rel, a szervezeti kommunikációval szemben támasztott új szakmai gondolkodás elméleti és gyakorlati követelményeire. 


\section{A kommunikáció, az információs társadalom törvényszerúségei}

A kommunikáció minden emberi magatartás, cselekvés természetes velejárója. Mondhatni, minden magatartás egyben kommunikáció (Watzlawick, Beavin \& Jackson 1968) és minden kommunikáció egyben magatartás. Ezért is vélekednek többen úgy, hogy minden kommunikáció (vagy mint eszköz, vagy mint kód, vagy mint cél, vagy mint megnyilvánulás), míg mások szerint, minden adat (Dudás, 2012), amelynek tartalma lehet információ, gondolat, érzés, meggyőződés. A kommunikáció általános értelemben nem más, mint a közlés útján megvalósuló információcsere. Fogalmi megközelítésem szerint a kommunikáció a kifejezés bármely módján vagy formájában megvalósuló információcsere. Az információcsere megvalósulhat információkérés, -gyűjtés, -átadás, -továbbítás vagy megtagadás, illetve tartózkodás útján (Buday-Sántha, 2016).

A kommunikációnak végtelen tartalmi összetevője, megnyilvánulási alakzata (a kokárdán át a Facebookig), és jelentéstartalma van. Korszakunkban a kommunikáció tartalmát képező információ már egyrészt tömegigény (tömegszükséglet), másrészt tömegtermék. A kommunikáció természete, hogy generatív hatású. A kommunikáció kommunikációt szül. A médiumok a kommunikáció generatív hatását sokszorozzák, ezáltal képződik a többszintű nyilvánosság, a modern társadalom kommunikációs rendszere (TKR). Egyúttal a medializálódás eredménye az interaktív, tömegméretű kommunikáció, a nyilvánosság szerkezetváltozása (Buday-Sántha, 2018).

A jelzett tényezők és az új technikai eszközök nyújtotta lehetőségek mozgatják az információs-kommunikációs társadalom fejlődését, ahol a tapasztalat, a hatalom és a kultúra új folyamatai jelennek meg (Castells, 2005). Az információs társadalom alapja a kommunikáció, erre épül az új társadalmi rendszer. Az információs társadalom - meglátásom szerint - az információáramlásra, a digitális írástudásra épülő olyan információközpontú tudástársadalom, amelyet az egyéni, szervezeti, társadalmi, gazdasági, politikai fejlődés, a versenyképességet biztosító információs technikák, technológiák innovatív alkalmazása és annak széleskörű, minden területre (pl. politikai, gazdasági, szociális, kulturális és humán jogrendszerre) kiterjedő beágyazódása jellemez. Jelenleg ennek mértéke, formája és módja országonként eltérő, ahogy az információs szegregáció, és esélyegyenlőség is. Az információ, adat, a kommunikációs rendszerek és médiumok birtoklása azonban mindenhol hatalmi tényező, ezért folyik a verseny. Világszintű jelenségei pl. adatvagyonok, az információ-, a vélemény-, médiamonopóliumok, az információgyarmatosítás vagy a kommunikációval való visszaélés (Buday-Sántha, 2020). Tom Lewis (2015) szerint az egyéni gazdasági érdeket szolgáló kereskedelmi üzenetek túlsúlyának lehetünk tanúi, amellyel szemben a közösségi érdekek megnyilvánulásához nincs pénz, ezért a gazdag egyének érdekének dominanciája uralja a világot, a piacgazdaságot. A szocialista berendezkedésű országokban az egyensúlyvesztésnek pont az ellentéte jellemző.

Az egyéni, szervezeti és társadalmi kommunikációt, a nyilvánosság és a média szerkezetváltozását a hálózatosodás, a social média szerepének folyamatos növekedése, a tömegméretűség fokozódása és az információs technológiák, a mesterséges intelligencia innovatív alkalmazása jellemzi. Ez növeli egyrészt a kommunikáció szabadságfokát, a társadalmi fejlődés lehetőségét, másrészt termeli az új, rendezetlen társadalmi viszonyok és 
kommunikációs helyzetek tisztázásának, a megfelelő normarendszer kialakításának igényét. Az információs társadalmakban jelenlévő integrált kommunikációt integrált normarendszernek kell követnie.

\section{A társadalom kommunikációs rendszere, a média és a nyilvánosság szer- kezetváltozása}

A különböző szinteken lezajló kommunikáció, leginkább társadalmi mérete alapján megkülönböztethető: egyéni, szervezeti (vagy csoport) és tömegkommunikáció. E három kommunikációs forma közül a legnagyobb hatással a tömegkommunikáció bír, hisz a közvéleményre ez képes a legnagyobb befolyást gyakorolni, ezzel alakítva az egyéni és a társadalmi tudatot, kommunikációt és cselekvést. Különösen igaz ez az információs társadalmak környezetére, ahol az informatikai rendszerek, a világháló, illetve a mobil-kommunikációs eszközök segítségével ma már bárki - lehet akár természetes, akár jogi személy, akár civil vagy állami-, önkormányzati szervezet - képes tömegkommunikációs hatás kiváltására. Modern világunkban alapvetően ez a forma jellemző a társadalmi kommunikációra, és biztosítja az üzenetek nagy tömegekhez való, szinte azonnali eljutását (Gálik \& Polyák, 2005). Véleményem szerint, a tömegkommunikáción, a kommunikációnak azt az intézményes megjelenési formáját értjük, amelyben a közlések nyilvánosan terjesztett eszközök, a médiumok útján, bármely módon, a heterogén tömeg vagy meghatározott célcsoportok felé kerülnek közvetítésre.

E folyamatban kiemelt szerepet játszik a média, mely a társadalom kommunikációs rendszerében létező „kommunikációs eszközök és intézmények összessége.” (Gálik \& Polyák, 2005, p. 18) Különös jelentőséggel bír az újmédia, új típusú internetes és mobilkommunikációs médiumok, amelyek az információkat, híreket, eseményeket közvetítik a társadalom vagy annak meghatározott csoportjai, egyénei felé. Balle a médiát berendezésként közelítette meg, amely lehetővé teszi, hogy az emberek kommunikáljanak, kifejezzék gondolataikat, függetlenül a kifejezés formájától és céljától (Balle, 2007; Ambrus, 2010). Randall a média és az információ tömegtájékoztatásban betöltött szerepére utalva azt állítja, hogy a médiának kitüntetett szerepe van az információ konstruktív hasznosítása tekintetében. A média olyan információkat, adatokat közvetít, amelyek helyettesítik a híreszteléseket és spekulációkat, tájékoztatja a polgárokat, monitoringozza, nyomon követi a kormányzat tevékenységét, a társadalom számára állandó jelleggel olyan „tükröt tart”, amely megmutatja az erényeket, de a hibákat is, leépíti a tabukat, biztosítja, hogy igazságot szolgáltassanak és vizsgálódjanak az igazság felderítése érdekében, lehetővé téve az eszmék, az információk szabad áramlását, a különböző vélemények ütköztetését. Meglátása szerint, ilyen értelemben a jó újságíró jobban szolgálja a társadalmat, mint a leglelkiismeretesebb hatóság (Randall, 1998). Egy más megközelítésben, Szekfü András a tömegkommunikáció és a civil társadalom viszonyáról úgy vélekedik, hogy a társadalom is tudja a tömegkommunikáció szféráját többféle módon befolyásolni. Az egyéni kifejezés eszközeinek igénybevétele esetén ez akár sokszori áttételt jelenthet. Közvetlenebb hatást gyakorol a közönség mint befogadó, fizető fogyasztó, illetve mint a közönségmérések által nyilvántartott reklámfogyasztó (Szekfü, 2001; Ambrus 2010; Béres \& Horányi 1999). 
A média önálló hatalmi ágazattá, társadalmi - befolyásolási - közhatalommá vált, amely tematizálja a közbeszédet (Buday-Sántha, 2018). Olyan „kapuőr” szerepet játszik, amely „eldönti” milyen információk kerülnek nyilvánosságra. Ezáltal meghatározó szerepe van a nyilvánosságra kerülő, a társadalom tagjai számára megismerhető, hozzáférhető információkra, eseményekre. A média tehát a nyilvánosságnak szánt információk útján tematizálja a közvéleményt, mivel a társadalom tagjai döntően a média, újmédia útján tájékozódnak. Ennek a folyamatnak résztvevői, azaz a társadalmat alkotó egységek (egyének, csoportok, szervezetek) kommunikációjának összessége alkotja a társadalom kommunikációs rendszerét. Az információáramlás behálózza az egész társadalmat. Olyan, mint az emberi idegrendszer.

A társadalmi kommunikáció rendszerének központi kategóriája a nyilvánosság, amely a kommunikációs tevékenység megnyilvánulásait a nyilvános kommunikáció tárgyává teszi, és a sokféleség jellemzi. A közvélemény a nyilvános kommunikáció tere és fóruma, amely személyek, csoportok és szervezetek között zajló társadalmi kommunikáció (Malkovics, 2007). Petrétei fogalmi megközelítése szerint a publicitás: „olyan közvetítő rendszer, ahol a közvélemény formálódik azáltal, hogy megvalósul az információk, nézetek, vélemények, törekvések széles körű cseréje, terjesztése, ütközése, összegzése és nyilvános kezelése" (Petrétei, 1998, p. 127).

A nyilvánosság és a társadalmon belüli kommunikáció egymásra kölcsönösen hatással van. A nyilvánosság alakulásának több korszakát, szerkezetváltozását jelölhetjük meg, melyen belül a szereplők és környezetük más-más jegyeket viselnek magukon. A társadalmi nyilvánosság torzulását mutatja be Habermas, miszerint a tömegmédiumok manipulációja inkább akadályozza a közönség racionális véleményalkotását, mintsem elősegítené azt. Leszögezi, hogy a magánélet szinte valamennyi területét szabályozása alá vonó állam, valamint a magánérdekek szolgálatában álló reklám és PR, a tömegkommunikációs eszközök segítségével a magánélet legbelsőbb közegeibe, a családi intimszférába való behatolása által megváltoztatta a nyilvánosság szerkezetét. Ez volt a nyilvánosság első struktúraváltása (Habermas, 1971). A nyilvánosság terét a média sokszínűsége növelte, mely a médiaszabadság megvalósulásának fontos eleme, és a demokratikus nyilvánosság előfeltétele (Bayer, 2017). Meyrowitzn szerint, a sokcsatornás tömegkommunikáció elterjedése úgyan kiszélesítette a nyilvánosságot, de a tömegkommunikációs eszközökkel megteremtett nyilvánosság lerombolta a privát és a köz közötti határokat (Meyrowitzn, 1986; Heller 2014).

A médiabirodalmak megjelenésével a polgári nyilvánosság fokozatosan vesztette el eredeti függetlenségét. Így a szabad nyilvánosság törvényszerűen alakult át hatalommal áthatott, manipulált nyilvánossággá (Malkovics, 2007), ahol a nyilvánosság feltétele a tömegkommunikációs eszközök nyitottsága, sokszínűsége, illetve a szabad publicitás. A nyilvánosság és a közvélemény egymást csak részben fedő, metsző halmazokat képeznek. Vannak olyan témák, amelyek ismeretlenek maradnak a közönség számára, míg a közvélemény egyes témái soha nem válnak a nyilvánosság témájává. De fordítva is igaz, hogy bizonyos adatok, információk nyilvánosságra kerülnek, de azok nem érdeklik a közvéleményt. 
Az információ korszakában az információnyilvánosság mind nagyobb teret nyer. Az „új információs és kommunikációs eszközök radikálisan átalakították a kommunikációs helyzeteket, azok korlátait, valamint a társadalom kommunikációs szokásait és mintáit" (Heller, 2014, p. 1), amely az információ korában új struktúraváltást hoz magával. A mediatizált, átpolitizált és kommercializált kommunikáció új perspektívába helyezi a nyilvánosságot, mely egyre inkább a magánszféra felé tolódik el. Az új információs technológiák elterjedésével és a kommunikációs eszközök sokfélesége által hozzáférhető különböző kommunikációs szintek, sokasodó nyilvános fórumok megjelenése folytán nem tartható fenn a korábbi, „egyetlen nyilvánosság fikciója,” helyette különböző kiterjedésű nyilvánosságok egymást átfedő szintjei alakulnak ki (Heller \& Rényi, 2000), a különböző szintű nyilvánosságok egész sora jellemző. A korábbi egységes nyilvánosság-fogalommal szemben ma a "nyilvánosságok különböző méretű, egymást átfedő, és egymásba kapcsolódó komplex mozaikja" a jellemző (Keane 1966).

A nyilvánosságra kerülő információkkal az egyes médiumokban, médiaplatformokon más-más megközelítésből bemutatva találkozhatunk. A befogadói oldalon az információ szelekció (melynél fontos kiválasztási szempont a saját értékrendét képviselő médiaválasztás) és szegregáció (az információs esélyegyenlőtlenség következtében a nyilvánosság fórumaitól, médiumoktól elzártságot jelzi) ugyancsak befolyásolja a közönség tagjainak médiafogyasztását. Az eltérő információforrás, illetve médiaválasztás folytán eltérő valóságképek alakulnak ki, ahol a digitális kommunikációs eszközök, a social média platformok és a mesterséges intelligencia innovatív technikai megoldásai más valóságszinteket és képzeleteket, párhuzamos valóságokat szülnek, melyek új értékartikulációra képesek. Ez az átalakulás determinálja a szervezeti kommunikációt, a média és PR viszonyát, egyben a vállalatok által alkalmazott PR stratégiát és taktikát, valamint ennek eszközrendszerét, illetve használatát. E környezetet tovább formálják a globális trendek, mint pl. a globalizáció, mesterséges intelligencia, robotika térnyerése vagy a világméretű COVID járvány.

A Reuters Intézet a „Digital News Report 2021” jelentésében a koronavírus járványnak a közönségre és a médiapiacra, híriparra gyakorolt hatását „sötét felhő”-ként értékelte. Jelentésben megfogalmazott általános trendek a következők:

- A válság - kiegészítve lezárásokkal és egyéb korlátozásokkal - növelte a nyomtatott újságok számának csökkenését, a független médiacégek anyagi nehézségeit, az újságírói elbocsátások számát. A fizikai lezárások negatív hatással voltak a nyomtatott sajtó terjesztésére, felgyorsítva a digitális médiafogyasztást. A jövő a digitális média.

- A hirdetők megijedtek a globális gazdasági visszaeséstől, és felülvizsgálták kiadásaikat, hagyományos hirdetéseiket.

- Új üzleti modellek jelentek meg, mint például az előfizetésre és tagságra épített forrásbevonás. A médiakiadók az előfizetőkhöz fordultak tagság és adományok végett, hogy csökkentsék a rájuk nehezedő nyomást.

- Nőtt a különbség a „legjobb és a többi” médium között, ahogy a bizalmi különbség a hírmédia és a közösségi média között.

- A hírek iránti bizalom átlagosan hat százalékkal nőtt, pont a koronavírus-járvány nyomán. A médiafogyasztók közül a legtöbben a hírben bíznak. 
- A megbízható márkák online is jobban teljesítenek.

Aggasztó egyenlőtlenségeket tárt fel a kutatás a közönség és a hírfogyasztás terén. A félrevezető, hamis információk és összeesküvés-elméletek globális terjedése általános trend. A felmérés azt mutatja, hogy aggodalomra ad okot a félretájékoztatás, miszerint:

- az idei évben 2\%-val nőtt a hamis információk aránya (58\%);

- területi megoszlásban a legnagyobb aggodalomra ad okot Afrika (74\%), ezt követi Latin-Amerika (65\%), Észak-Amerika (63\%), Ázsia (59\%), és a legalacsonyabb Európában (54\%);

- az emberek átlagosan azt állítják, hogy többet láttak hamis és félrevezető információkat a koronavírusról (54\%), mintha politikáról van szó (43\%);

- hamis információk egyéb témái, 29\%-ban hírességekhez (színészek, zenészek és sportsztárok), 22\%-ban termékekhez és szolgáltatásokhoz, valamint 20\%-ban az éghajlatváltozáshoz kapcsolódnak (Newman et al., 2021).

\section{A PR, a hírnévépítés elvei}

A Public Relations (PR), „Vagyis a stratégiai kommunikációmenedzsment a menedzsment tudományok egyik legdinamikusabban fejlődő területe." (Konczosné, 2014. p. 461) A média és nyilvánosság nyújtotta keretek közt lehet, illetve kell egy adott szervezet hírnevét építeni, és gondozni. Az erre irányuló PR tevékenység, olyan összetett menedzsment tevékenység, amely a tudatos szervezeti kommunikációszervezéssel szolgálja a környezetével a kölcsönös megértést, a jóakaratot és a bizalmat. A sikeres PR tevékenységhez állandó interakcióban kell állni környezetünkkel, hisz a public relations annak az eredménye, „amit teszel, amit mondasz, és amit mások mondanak rólad.” (Gregory, 1996, p. 15) A hírnév pozitív alakítása érdekében nélkülözhetetlen annak a PR stratégia alapelvnek az alkalmazása, miszerint: „Beszélj a környezeteddel arról, amit megtettél, megteszel, vagy tenni akarsz. Mondd el nekik céljaidat, kérdezd meg véleményüket, és így a tájékoztatás, a megértés és a visszacsatolás után vond be őket tevékenységed alakításába." (Baráth, 2001) A bizalomépítés művészetét az előzőekben vázolt környezeti változásokra figyelemmel megfogalmazott szakmai és gyakorlati elvek mentén lehet csak hatékonyan müvelni.

A szervezeti hírnév meghatározó elvei közül kiemelendők:

A PR tevékenységnek követnie kell a külső környezet változásait és elvárásait, melyek közt fontos szerepet játszik az etikus vállalati működés is. A PR, a hírnévépítés újrafogalmazott elvek mentén működtethető hatékonyan. Ezek:

- a megkülönböztethetőség elve (sajátos jelleg, egyedi megjelenés, pozicionálás);

- a láthatóság elve (az állandó médiajelenlét, médiaszereplés);

- a következetesség elve (konzekvens, kiszámítható tevékenység, szervezeti magatartás, és megbízható kommunikáció);

- a hitelesség elve (a vállalati identitás és az image kompatibilitása, valós információk, valós kép biztosítása); 
- a jogszerű és etikus vállalati működés elve. A jogszabálysértések és etikai sérelmek komoly hírnévkockázatot jelentenek, és etikus vállalati működés nélkül nincs sikeres PR tevékenység.

- a transzparencia elve (a szervezeti átláthatóság, az átlátható információ és kapcsolatkezelés). (Fombrun-Riel 2004; Szeles, Szűcs \&Varga 2013)

Az információs és kommunikációs forradalom, a digitalizáció, az újmédia és eszközei olyan paradigmaváltást eredményezett, amely új hangsúlyok, új kommunikációs stratégia kialakítását indukálták, s ezt a szükségszerűséget csak tovább erősítette a gazdasági és egészségügyi világválság. Az új helyzetben a hatékony, sikeres PR tevékenység nem nélkülözheti:

- a világos jövőképet, az elkötelezett vállalatvezetőket, és a lehetőségeket kiaknázó piaci jelenlétet;

- az integrált kommunikációs stratégiai gondolkodást (mint pl. a kommunikációs eszközök generatív hatására épülő kommunikációs mixet);

- a kommunikációs-, és hírnévkockázatok minimalizálását (amelyhez szükséges pl. a proaktív tájékoztatási politika, a piac-, és kockázatelemzés, az etikai és jogi normák betartása, a kríziskommunikációs terv, és a belső kommunikációs szabályzat megléte, adatvédelem és adatbiztonság);

- a külső és belső PR összhangjának biztosítását (mint pl. a külső PR tevékenység mellett nem hanyagolható el a belső PR, a dolgozói lojalitás, elkötelezettség erősítése, a megfelelő munkahelyi környezet biztosítása, és dolgozói kommunikációs képzések, tréningek sem);

- az indirekt eszközök hatékony használatát (mint pl. támogatási formák, CSR tevékenység);

- az újmédia, a mobilkommunikációs és közösségi média platformok nyújtotta lehetőségek kiaknázását (mint pl. a social média és online eszközök);

- az egyedi kifejezési eszköz kidolgozását („Annyi PR eszköz, ahány PR szakember.” Az egyedi eszközök, lehetőségek mindig az adott vállalat speciális jellemzőiből meríthetők. Egyedi PR alapeszköz minden szervezetnél a sajátos, megkülönböztethető arculati elemek, és azok egyedi felületei, amelyek magukban hordozzák a szervezet érzelmi és értelmi attitűdjét, értékrendjét.);

- a külső személyek (pl. neves személyiségek, hiteles szakértők, véleményvezérek) és a saját fogyasztói/megbízói/dolgozói kör bevonását a szervezeti kommunikációs tevékenységbe;

- a saját médiaplatformok számának folyamatos növelését (mint pl. a Facebook és más social média profil, e-hírlevél, vezetői blog, twitter bejegyzések);

- állandó információ-kibocsátást, médiajelenléte, és a pozitív hírgenerálást;

- rövid, egyértelmű üzenetek konzekvens használatát (figyelemmel az újmédia új nyelvi sajátosságaira, valamint olyan szlogenek megfogalmazására, amelyek a nyelvi lehetőségek - szólás, mondás, aforizma, humor (stb.) - felhasználásával könnyen köthetők valamely közismert információhoz); 
- tematizált és célcsoport specifikus üzenetek (a kommunikáció adott téma köré összpontosított) alkalmazását;

- a célcsoportok pontos szegmentálását (amely elősegíti az üzenetek hatékony célba jutását);

- naprakész és széleskörű sajtóadatbázis ápolását (pl. a médiumok gyors elérhetőségéhez);

- az utókövetést, a kommunikációs eredmények feltárását, mérését, elemzését (pl. sajtófigyelés, médiaanalízis, piaci felmérés, trendfigyelés és jövőkutatás alkalmazásával);

- az etika vállalati intézményesítését;

- a szervezet kommunikációs szakembereinek összehangolt napi tevékenységét (sok vállalatnál külön egységek, szakemberek foglalkoznak pl. a marketinggel, a PR tevékenységgel, és az ügynökségi támogatás esetén a hatékonyság a közös munka eredményességének fokmérője, mivel ezek erősítik, de akár ki is oltják egymást); (BudaySántha, 2021).

\section{PR és etika}

\section{Az etika szerepe a szervezeti kommunikációban, PR-ben}

A tanulmányban bemutatott trendek és „a mindent átható mediatizáció lényegét tekintve olyan metafolyamat, amely a média által közvetített történetek interiorizálása révén átalakítja a szocializáció, a társadalmi élet teljes feltételrendszerét, új társadalmi formákat is teremt, és eddig ismeretlen árnyalatokkal gazdagítja a kommunikáció közösségformáló szerepéről alkotott képünket is." (Szécsi, 2019, p. 14) Ez az átalakulás új feladat és felelősség elé állítja a szervezeteket, kommunikációs, PR menedzsereket. A gyors környezeti, technológiai átalakulás determinálja a szervezeti kommunikációt, a vállalati-szervezeti etikát és moralitást. A szervezeti kommunikációnak, a hírnévmenedzsmentnek alapkövetelménye az etikus vállalati magatartás a társadalmi felelősségvállalással karöltve, amelyeknek ugyancsak központi témája az etika intézményesítése.

Az elmúlt évtizedekben jelentős fejlődés figyelhető meg az etika intézményesítése terén világszerte, mely több okra is visszavezethető. Az etikai intézmények formáit, eszközrendszerét a folyamatos gazdagodás jellemzi. A Szegedi és Szilágyi által 2013-ban végzett kutatás eredményei szerint, a nagyvállalatok felismerték, hogy etikus magatartás nélkül nem érhetnek el tartós piaci sikereket: „A hazai nagyvállalatok körében az utóbbi 5-9 évben volt jelentős fejlődés az etika intézményesítésében. A legelterjedtebb etikai intézmény az etikai kódex. A kódexszel rendelkező vállalat rendszeresen kommunikálja etikai normáit a vállalaton belül. Emellett bevezettek más etikai intézményeket is, mint például a tréning, a bejelentőrendszer, a bizottság. Kevéssé elterjedt a vállalattól független ombudsman és a külső audit. Az etikai kódexet bevezető nagyvállalatok 95\%-a szerint, pozitív hatása van az etika vállalati intézményesítésének." (Hungarian Business Leaders Forum, n.d., p. 2.)

A vállalatok alapvető stratégiai célkitűzései közt nyer megfogalmazást az etikus magatartás, mely a szervezet életében pozitív változásokat vetít elő. Az adott vállalat etikus 
működésének alapját a szervezet alapvető értékeinek, alapelveinek meghatározása és ennek a vállalati élet mindennapjaiba történő integrálása képezi. A megvalósítása folyamatjelleget ölt. Az etika intézményesítésének fókuszpontjai: az elhatározás, a megfogalmazás és írásba foglalás, a szervezet működési folyamataiba történő integrálás, a személyi és szervezeti háttér megteremtése, a tudatosítás és az ellenőrzés. Ennek kialakítása, végrehajtása és múködtetése azonban jelentős szervezeti, személyi és anyagi feltételek biztosítását igényli (Buday-Sántha, 2016).

Az etikai intézmények, olyan vállalati szintű formalizált képződmények, amelyek a vállalati kommunikáció és a társadalmi felelősségvállalásnak is megnyilvánulásai. Az etikai intézmények több szempont szerint csoportosíthatók. Eszerint léteznek külső és belső irányultságú intézmények, de elkülöníthetők a formális és informális, a hagyományos és egyedi, valamint a direkt és indirekt eszközök is. Az etikai intézmények fókuszában az Etikai Kódex áll. Az intézmények a szervezeti oldalról, a kommunikációs csatornákba történő beágyazódás és a visszacsatolási rendszer oldaláról megközelítve három főbb csoportba rendezhetők. A legismertebb és leggyakoribb formalizált etikai intézményeket az alábbi ábra reprezentálja.

1. ábra: Etikai intézmények

\section{ETIKAI KÓDEX}

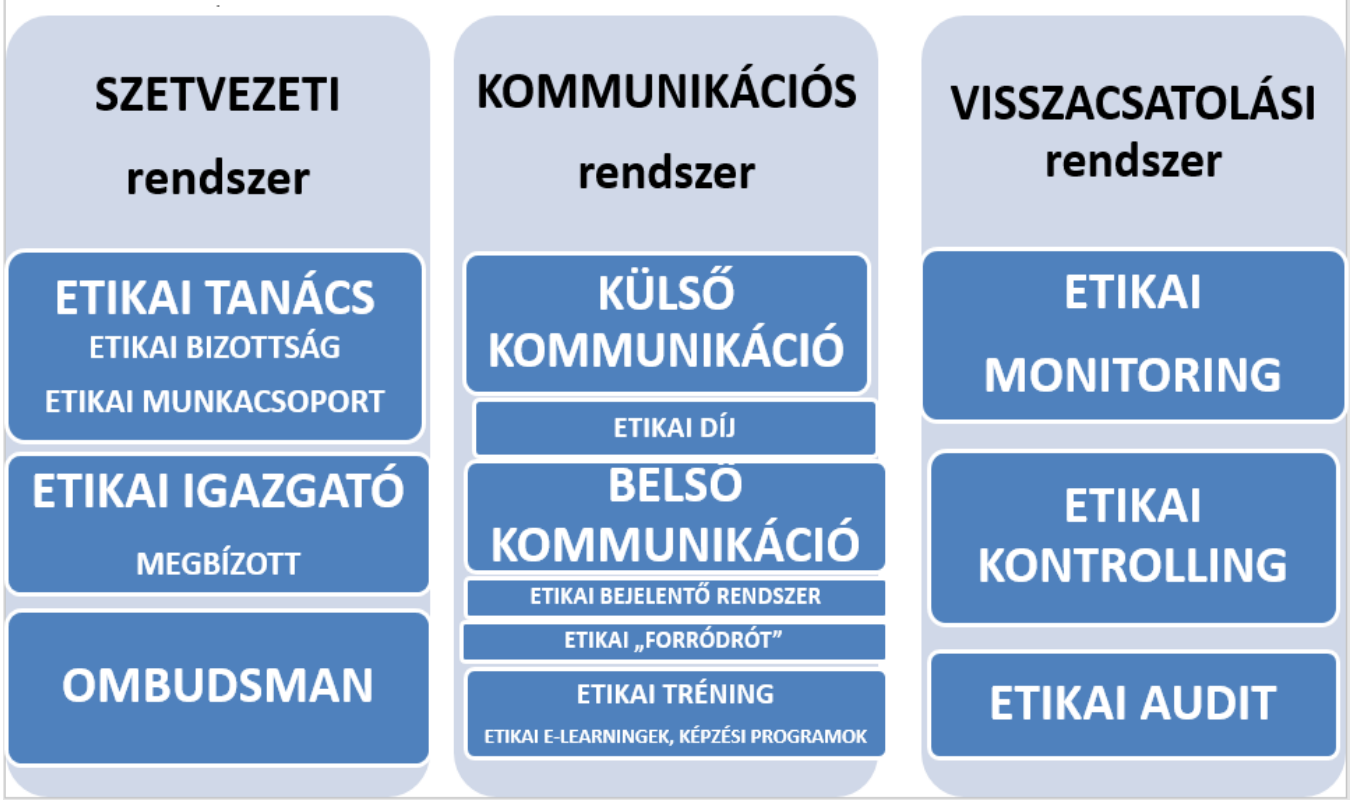

Forrás: Buday-Sántha, 2016, p. 37

Az ábra jól szemlélteti a szervezeti etika és a szervezeti kommunikációs rendszer szoros kapcsolatát, melyek egymásra kölcsönösen hatnak. Az Etikai kódex az intézményrendszer fókuszában elhelyezkedő alapeszköz zsinórmértékül szolgál a teljes vállalati működés számára. Deklarálja a vállalat által elvárt, elfogadott vagy elutasított magatartás-, viselkedésmintákat, és ezzel kijelöli a határokat. Az alapértékek kódexbe rögzítése elősegíti az értékkövetést, az etikai szabályok tudatosítását, és az ezzel autentikus magatartásformák tanúsítását. 


\section{Etikai sérelmek fő területei}

A kommunikációs iparág működése során nap, mint nap találkozhatunk etikai problémákkal, kommunikációs visszaélésekkel. A kommunikációs sérelmek tárgyában, 2014ben, „A Kommunikációs jog és rendszere” c. PhD értekezésemhez végzett, a releváns sokaság célzott kiválasztására tudatos, célcsoportorientált mintavételével alapján, önkéntes, anonim, kérdőíves felmérés, primer kutatási eredménye szerint a leggyakoribb normasértések területei: a kéretlen levelek, spamek, promóciós termékek, a jogtalan adatkezelés és felhasználás; a személyhez füződő-, szerzői jogok és a jó hírnév sérelme. Nemzeti és világgazdasági szinten egyaránt mérhető kárt jelent, hasonlóan a kiber támadásokhoz (Buday-Sántha, 2016). A szervezeti etikai normasértéseket három fő csoportba sorolhatjuk. Az első csoportba az általános, mindenki által elfogadott emberi alapértékek sérelmei, a másodikba a szervezet által deklarált etikai értékek sérelmei, a harmadikba a kommunikációs tevékenységgel okozott sérelmek tartoznak.

Az üzleti etika oxfordi kutatói már a kilencvenes években osztályozták a vállalatok működése során leggyakrabban fellépő etikai problémákat. A legsúlyosabb sérelmeket hat területre osztották: kapcsolattartás a fogyasztókkal, a fogyasztókról szóló információk, reklámozás, termékfelelősség, garanciavállalás és megvesztegetés (Sorrel \& Hendry, 1994).

A hazai nagyvállalatok körében végzett kutatás szerint, „az etikai bejelentések és vétségek leggyakoribb esetei: az összeférhetetlenség (36\%); a vállalati eszközökkel való viszszaélés (29\%); az ajándékokkal, szórakozással való visszaélés (19\%); a diszkrimináció (18\%); a megvesztegetés és korrupció (16\%); a zaklatás (14\%)." (Hungarian Business Leaders Forum, n.d., p.2.) Az etikai bejelentések, vétségek kutatási adatai rámutatnak arra, hogy a sérelmek jellege koronként, országonként, de még vállalatonként és üzleti területenként is eltérő.

\section{PR szakmai etika}

A PR szakemberek országos szakmai és etikai érdekképviseletét, érdekvédelmét a Magyar Public Relations Szövetség (MPRSZ) látja el. A Szövetség Etikai Kódexe (MPRSZ, 2020) deklarálja a PR szakma etikai értékeit, kötelességeit, és megadja az etikai eljárások jogi kereteit. Ezen értékek segítik a szervezetek saját etikai kódexeinek megalkotását is. A Szövetség Jogi és Etikai Bizottságának egy évtizedes elnöklése alatt a Bizottsághoz bejelentett sérelmeket (MPRSZ, 2006-2016) és tapasztalatokat összegezve az etikai sérelmek főbb ügycsoportjai határozhatók meg:

a) a személyiségi jogok, a jó hírnév sérelme, rágalmazó, nyilvános becsületsértő kijelentések;

b) a PR Ügynökségi szolgáltatással szembeni minőségi, szakmai és anyagi kifogások;

c) a médiakapcsolatok során felmerülő visszaélések;

d) a kreatív-, rendezvény ötlet copyright;

e) PR ügyfélkapcsolatok, üzleti titkok sérelme;

f) PR pályázati eljárás és eredmény kiszivárogtatása. (Buday-Sántha, 2016) 
Az MPRSZ örökös tagja, Sárosi Péter véleménye szerint, romlott az etikus kommunikáció helyzete, mert egy „eldurvuló” világban élünk. Álláspontja, hogy az etikus viselkedés a PR-ben tisztességes. A PR etika alapvetése, hogy nem hazudunk. Etikátlannak tartja a kommunikációt, ha valós tényeket nagyít fel, vagy valótlant valós színben állít be, vagy ha valamiről nem beszél, mert ezzel erősen torzíthatja a valóságot. De ami etikátlan, az nem feltétlenül jogsértő. Új etikai kihívásként fogalmazza meg az új social média eszközök megjelenését, amelyekkel könnyebb az etikai határokat átlépni az etikátlanság felé. Kívánatosnak tartja többek közt az új technológiához való alkalmazkodást (Sárosi, 2021).

Az előzők mellett, a szervezeti és szakmai etika vonatkozásában komoly veszélyként jelentkezik a társadalmi rendszer átpolitizáltsága, a populizmus, a kommercializálódás, az egészségügyi világjárvány, az általános értékválság, valamint olyan új jelenségek, mint az önkontrollt nélkülöző internetes közösségi terek, új social média eszközök visszaélésszerű használata, „fake news” terjedése, a morális pánik, a virtuális világ, a valóság 2.0, az információ-gyarmatosítás vagy a mesterséges intelligencia és a robotika. A visszaélések megelőzése igényli a kodifikációt, a normatív és non ius szabályozást, mint például a szervezeti etikai kódexek meglétét (Buday-Sántha, 2016).

\section{Összegzés}

A média, a nyilvánosság és a PR - mint a hírnévépítési tevékenység - nagyon összetett tényezők, melyekre sok külső hatás és belső tényező együttesen hat. Különösen napjainkban, az információs társadalmak felgyorsult világában, ahol a változás örök szabálya minden korábbinál jobban érvényesül. Ennek motorja a 4. ipari forradalomként emlegetett információs, kommunikációs forradalom és technológiai robbanás. A globális trendek, és a koronavírus járvány is új irányokra és új megoldásokra készteti a médiát, és a PR szakma művelőit. A kommunikációs és PR tevékenységnek követnie kell a külső környezet változásaira figyelemmel újrafogalmazott elméleti és gyakorlati szakmai elveket, melyek a hatékony hírnévépítést segítik elő. Az etika felértékelődött szerepét, az etikai intézmények fejlődését épp az emberi, etikai alapértékek elértéktelenedése és változó világunk új jelenségei táplálják. A szakmák, a piacok, a szervezetek az etikai intézmények bevezetésével, - ily módon az alapértékek demonstratív képviseletével és publikálásával - igyekeznek ellensúlyozni, egyben erősíteni a gyengülő egyéni, szervezeti, piaci és társadalmi moralitást. Etikus vállalati múködés nélkül, nincs eredményes PR tevékenység. 


\section{Irodalomjegyzék}

Ambrus, Z. (2010). Dreptul comunicárii (pp. 20-32). Miercurea-Ciuc: Status Printers Siculeni

Balle, F. (2007). Médias et sociétés. 13e édition, Montchrestien.

Barát, T. (2001). A bizalom tolmácsai. Medipen Bt. Kiadó.

Bayer, J. (2017). Media Pluralism in Third-Wave Democracies. The Potential of European Legislation to Improve Media Freedom and Pluralism. In Bajomi-Lázár, P. (Eds.), Media Pluralism in Third-Wave Democracies (pp. 19-44). L' Harmattan.

Béres I., Horányi Ö. (Eds.). (1999). Társadalmi kommunikáció (pp. 86-95). Osiris Kiadó.

Buday-Sántha, A. (2016). A kommunikációs jog és rendszere. PhD értekezés. http://ajk.pte.hu/doktori-iskola/vedesek.

Buday-Sántha, A. (2016). Az etika íratlan szabályainak világa. In Sós, P. J.; Szécsi, G. (szerk.): Etika a PR-ban, PR a városban: A Public Relations elmélete és gyakorlata. (pp. 24 -51) B. SWAN Partners Kft.

Buday-Sántha, A. (2018). Kommunikációs jog. A kommunikációs jog és „Hálómodell”. Fakultás Kiadó.

Buday-Sántha, A. (2019). A kommunikációs jog, mint új tudományos és management kihívás. Marketing \& Menedzsment, 53(3), 67-76.

Buday-Sántha, A. (2021). Üzleti és PR etika. Az üzlet etikai és a kommunikációs - szakmai etika aktualitásai. Kultúratudományi Szemle, 2021(2).

Castells, M. (2005). A hálózati társadalom kialakulása. Az információ kora: Gazdaság, társadalom és kultúra. (I. kötet), Gondolat - Infonia.

Dudás, G. (2012). Alapfogalmak. In Péterfalvi, A. (szerk.), Adatvédelem és információszabadság a mindennapokban (p. 60). HVGORAC Lap- és Könyvkiadó.

Fombrun, C. J. \& Riel, C. B.M. (2004). How Successful Companies Build Winning Reputations (p. 86). Fame\&Fortune, Financial Times Prentice Hall.

Gálik, M. \& Polyák, G. (2005). Médiaszabályozás. KJK-KERSZÖV Jogi és Üzleti Kiadó.

Gregory, A. (1996). Planning\&Managing a Public Relations Campaign (A step-by-step guide). Institute of Public Relations, Kogan Page.

Habermas, J. (1971). A társadalmi nyilvánosság szerkezetváltozása. Gondolat Kiadó.

Heller, M \& Rényi, Á (2000). A nyilvánosságfogalom kommunikáció-elméleti megközelítéseirõl, Jelkép, 2000(1), 69-94.

Heller, M (2001). Új kommunikációs helyzetek és szükségletek: A hierarchikus nyilvánosságok kialakulása (pp. 1-5). http://wap.phil-inst.hu/2001_marc/brosura_htm/heller.htm.

Hungarian Business Leaders Forum (n.d.): Az etika vállalati intézményesítése. https://hblf.hu/content/_common/attachments/etika_egylapos.pdf

Keane, J (1966). Structural transformation of the public Sphere. The Communication Review, 1966(1), 1-22. Konczosné, Szombathelyi M. (2014). A megújuló hírnév. In Marketing megújulás. Marketing Oktatók Klubja 20. Konferenciája előadásai (pp. 459-467). http://acta.bibl.u-szeged.hu/57682/1/marketing_megujulas_459-467.pdf.

Lewis, T. (2015. április 24.): Az aktivizmustól az önkorlátozásig. Előadás. Budapest New Media Word 2015 - International Conference.

Malkovics, T. (2007). Nyilvánosság és közvélemény. In Tanulmányok a társadalmi kommunikáció témaköréböl. L'Harmattan.

Meyrowitz, O. (1986). No Sense of Place. The Impact of Electronic Media on Social Behavior. Oxford University Press.

MPRSZ (2006-2016). Etikai Bizottság - Etikai bejelentések, 2006-2016, Budapest.

MPRSZ (2020. július 25.). Etikai Kódex. https://www.mprsz.hu/etikai-kodex/.

Newman, N., Fletcher, R., Schulz, A., Andı, S., Craig T. Robertson, C.T. \& Nielsen, R. K. (2021): Digital News Report 2021, Reuters Intézet. https://reutersinstitute.politics.ox.ac.uk/sites/default/files/202106/Digital_News_Report_2021_FINAL.pdf.

Petrétei, J. (1998). A törvényhozás elmélete és gyakorlata a parlamentáris demokráciában. Osiris Kiadó. Randall, D. (1998). Jurnalistul universal. Editura Polirom. 
Sárosi, P. (2021). Romlott a kommunikáció etikája az elmúlt évtizedekben. Interjú Sárosi Péterrel, az MPRSZ örökös tagjával. https://www.mprsz.hu/romlott-a-kommunikacio-etikaja-az-elmult-evtizedekben-interjusarosi-peterrel-az-mprsz-orokos-tagjaval/.

Sorrel, T. \& Hendry, J. (1994). Business Ethics. Wallingford. AwesomeBooks.

Szécsi, G. (2019). Énteremtő narratívák az új média korában. Kultúratudományi Szemle (Cultural Science Review), 1(2-3), 14-22.

Szegedi, K. (2001). A magyar vállalatok etikai érzékenysége. PhD értekezés. http://midra.uni-miskolc.hu/JaDoX_Portlets/documents/document_5526_section_1005.pdf.

Szekfü, A. (2001).A szervezetek kommunikációjáról. In Béres, I. \& Horányi, Ö. (szerk), Társadalmi kommunikáció (pp.92-93). Osiris Kiadó.

Szeles, P., Szűcs, T. \& Varga, Zs. (2013). Hírnév - menedzsment. Révai Digitális Kiadó.

Watzlawick, P., Beavin, J. A. \& Jackson, D. D. (1968). Pragmatics of Human Communication. Az emberi kommunikáció. Faber and Faber Co. http://www.communicatio.hu/hg/kommelm/texts/watzlawick.htm 